\title{
The Development of Achievement of Women Judo Athletes from West Java
}

\author{
Ira Purnamasari* \\ Pendidikan Kepelatihan Olahraga \\ Universitas Pendidikan Indonesia \\ Bandung, Indonesia \\ *irapurnamasari@upi.edu
}

\begin{abstract}
As one of martial sports that is generally preferred by men, Judo is considered as a tough sport for women. Besides, social and cultural aspects also don't support women to play Judo. West Java is one of barometers for Judo sport in national level. West Java athletes on Judo made a great achievement in the last three Pekan Olahraga Nasional events by successfully become the champion, in which women athletes brought more medals and made West Java as the champion. The study was aimed at investigating on gender discrimination on sports by focusing on parenting dealing with how to be athlete through a long and sustainable process. The study was set as a qualitative research whose data were collected through observation, interview, and documentation study. In addition, the data were also collected through interview with expert on sports and history of Judo. The result of study shows that a dissemination of sports to women is better to be conducted during childhood by transferring values, knowledge, and building good attitude from the level of family. Besides, social environment of young athletes is also considered effective to give a role model.
\end{abstract}

Keywords—judo; development; achievement; West Java

\section{INTRODUCTION}

Pekan Olahraga Nasional or what is called PON, is the most prestigious multi-events sport exhibition in Indonesia. Meanwhile, in international context, similar events are Olympiad, Asian Games, Asian Indoor and Martial Art Games and Sea Games. A multi-events exhibition, particularly in international context, is a good opportunity for every country to show their ability and pride of their own country. Once they win a title in a multi-events exhibition, such as Olympiad, they are able to promote their nation proudly [1]. Accordingly, sport events can be an effective means to promote a nation profile and pride [2]. The pride of winning a multi-events exhibition, particularly multi-events in international context, will also be gained by the individual athlete and their family. The wider the scope, the more prestigious the victory will be [1]. This will give greater motivation to the athlete to make more achievement in their carrier.

In a national context, getting medals in PON is considered as a great achievement that can be a good chance for every province to upgrade their prestige. Judo is one of sports that has been a medals getter for West Java in PON since Judo athletes tend to get gold medals for West Java PON contingents. One of West Java Judo's achievements is becoming the general champion in the PON 2016 in West Java and become one of sports that give great contribution to make West Java become the general champion in the PON 2016.

West Java Judo athletes have made great achievement. According to the data, West Java Judo team has become general champion in three PON events, in 2008, 2012, and 2016. In addition, in single event match, for instance Kartika Cup, Wismoyo Cup, etc., West Java Judo team also tends to be the top medals getter and most of them were given by women athletes. The study is particularly aimed to explore the development of women judo athletes' achievement from West Java.

In relation to this women Judo athletes' achievement, judo is in fact mostly preferred by men, instead of women [3] which can be seen by a small number of participation to this kind of sport. Judo is selected by women is usually due to its function as self-defense sport [4]. In literal meaning, Judo consists of two words, Ju which means gentle, and Do which means way. Thus, Judo means soft way, in other words someone can defeat others by using gentle ways. As a martial art, judo is now chosen by women as their self-defense. In addition, judo is also useful to improve physical condition [5].

\section{METHOD}

The study was set a descriptive-analytical research that use qualitative approach. The data gained is interpreted and its interpretation is made and arranged systematically and holistically. The method was employed since the data needed is complex, holistic, and dynamic. This kind of data in a particular social setting doesn't suit quantitative approach. The participants of the study were purposively selected by previously matching them with the requirements of the data needed: athletes, coaches, athletes' family, and holding team. The participants were selected based on their role and function to answer the research question. Sampling technique that was used to collect data is snow ball technique, which means that the number of participants keeps increasing based on the limitation of the study. Instrument of the study is the researcher that is also validated. The researcher as a human instrument play a role to decide focus of the study, choose the participant of the study that is able to be a source of data, choose data analysis technique, interpret the data gained, and to draw 
conclusion from their finding [6]. In collecting the data, the research used various tools such as tape recorder or camera. The data were collected in natural setting in which primary data were gained through observation, in depth interview, and documentation [6]. Observation was conducted to look at the participants' activities, their daily life, or other activities that may contribute to their achievement in multi-events judo match in national and international context. Besides, observation was also employed to investigate the development judo sports in Indonesia. Meanwhile, in depth interview was used to gain comprehensive information about issues that have been selected as the focus of the study. The data that are gained from observation and interview were corroborated and strengthen by reviewing literature.

\section{RESULTS AND DISCUSSION}

Parenting pattern in family is important to build children character and to prepare and train them be ready to mingle around their environment and to compete with others in a wider social setting. Brown asserts that "Family is an environment that accept children for the very first time." [7]. The acceptance and rejection of someone in their environment also relies on the way his/her parents raise them in his family.

Previous related research shows that an individual's participation in sports mostly depends on his/her family and his closest environment [8]. Parents play significant role in reminding their children about norms in the society and in building children character. Meanwhile, society is a place where children develop their personality and behavior. Children who have been given strong character building from their parents will face no difficulties when they are in the middle of a wider social environment. Parenting patterns that have been applied in the family can be seen and reflected in the child's behavior and point of view.

Besides, other factors may also contribute to an athlete's achievement. These cover physical condition, technical, tactical, and mental aspects as well as competition experience [9].

The first West Java athlete to join Sea Games is Ida Iriani Kandi. After that, West Java also has the first gold medalist in PON in 1992 namely Paula Vincentia Pantauw, who is actually from East Java but she has lived in West Java that made her delegate West Java in PON 1992.

The rest of Judo gold medalists in PON from West Java are listed in the table below.

TABLE I. JUDO GOLD MEDALISTS IN PON FROM WEST JAVA

\begin{tabular}{|c|c|c|c|c|c|}
\hline 1996 & 2000 & 2004 & 2008 & 2012 & 2016 \\
\hline $\begin{array}{l}\text { 1.Maya } \\
\text { F } \\
\text { 2.Ira P }\end{array}$ & $\begin{array}{l}\text { 1.Maya F } \\
\text { 2.Ira P }\end{array}$ & $\begin{array}{l}\text { 1. Maya } \\
\mathrm{F} \\
\text { 2.Tati R } \\
\text { 3.Teni A } \\
\text { 4.Ira P }\end{array}$ & $\begin{array}{l}\text { 1.Tati R } \\
\text { 2.Ira P } \\
\text { 3. Diah } \\
P\end{array}$ & $\begin{array}{l}\text { 1.Ira P } \\
\text { 2.Rina } \\
\text { M }\end{array}$ & $\begin{array}{l}\text { Terry K } \\
\text { Teni } \\
\text { Anggraeni } \\
\text { Tiara A } \\
\text { Szalsza M } \\
\text { Raisa P }\end{array}$ \\
\hline
\end{tabular}

Athlete $\mathrm{A}$ is one of woman judo athletes that has given most gold medals in PON for West Java contingents. Athlete A comes from a family who love doing sports. Athlete A's father is a judo coach that has successfully made his athletes become a champion in various national and international events. Athlete A's mother is very supportive, she always supports all her husband and her child sports activities. Athlete's A brother is a former Judo athlete that moved to MTB, meanwhile the second brother of Athlete $\mathrm{A}$ is also a judo athlete. This indicates that family has great effects on one's preference in doing sports [8]. Athlete $\mathrm{A}$ is a clear example about how she chooses judo due to family factor that is very supportive and conducive to do sports, particularly judo. Parenting pattern that has been applied during childhood will be faced to various decisions about what a child will choose. This fact reveals that the first parenting pattern someone get is from his/her family [7]. The parenting pattern applied by parents is able to determine child's personality since it is practiced for a long time in the family. In relation to parenting pattern, Geertz advices that "family should be a place for children to learn about values, social roles, norms, and also about customs that have been introduced" [10]. In addition to family factor, judo was also chosen by women as a self-defense sport to protect themselves when they are threatened [4].

Athlete B has given 3 gold medals for West Java in PON. Athlete B comes from Sukabumi. Her interest in Judo started to grow when she lives near Vihara and a place to have judo exercise. Athlete B comes from Chinese ethnic, who is believed by some people as one factor that may also give positive contribution to an athlete's achievement "The eagerness Chinese ethnic on their activities and also their hard work made them succeed" Djide said [7]. Besides this internal factor, environment around house is a good place to have social interaction among individuals in a society, and one of them can be carried out through sports [11].

Athlete $\mathrm{C}$ is a West Java athlete that has successfully given gold medal in PON 2016. Athlete C played judo when she was 11 years old. Her parents decided to make Athlete $C$ join judo since she was hyperactive. She actually joined Taekwondo, but finally moved to Judo. Easy access to the exercise place can also be a factor of how one chooses sport, as Athlete $\mathrm{C}$ choose judo due to its easiness to reach the Dojo that is able to help Athlete C to practice Judo.

From social aspect, gender difference is a point of view that is made by the society. There is still wrong and different point of view between gender and sexual difference. The difference between gender and sexual difference lies on three aspects that are related to biology and anatomy that covers: intern factor, extern factor, and akil baligh period [7]. Meanwhile, in relation to gender, Wood said "By implication, not only are you affected by social views of masculinity and feminist, but you are part of shaping those understandings [12]. Because each of us participates in cultural life, we affect it, including the meanings our society assigns to gender." Further, he added that "you see gender isn't just whether you are male or female, but it's the meaning culture attached to your sex".

Women participation in joining and doing sports is one of the examples how gender discrimination view isn't rejected [13]. Role, position and existence of a woman mostly depend on where and how she was raised [7]. Woman tends to pursue 
something by being affected by her environment. When women choose to join martial sports, she at the same time helps the society to eliminate gender gap. In addition, she also still wants to have beautiful body curve and to make herself more beautiful [14].

Someone's way of life in the society is derived from diverse culture that is shaped from the diverse ethnics existing in Indonesia and even in the world [7]. Culture doesn't view gender in the way whether someone is a man or woman, but on the meaning of culture itself on particular sexual type.

The diverse culture existing in Indonesia makes this country rich and different from other countries in the world. Indonesia has 370 ethnics and 67 languages. This made Indonesia to be the largest multi socio-cultural and multiethnics country.

The survival of role division in the society that last for a long time, according to Koentjaraningrat will be able to become an ideology [15]. Further, ideology that is part of a cultural system will be a difficult thing to be changed. In sports activities, for example, there is still role division for some kinds of sports where they are only deserved to be done by men (masculine sports). In fact, data shows that Indonesia women athletes that joined those masculine sports are able to make great achievement in national and international context.

\section{CONCLUSION}

Process of disseminating sports during childhood among women athletes is conducted by transferring values, knowledge, and by building behavior that is conducted in the level of family. In addition, social environment also plays significant role to give role model and motivation to the young athletes. Someone tends to choose a kind of sport based on intrinsic motivation at first, and then followed by her extrinsic motivation.

\section{REFERENCES}

[1] I. van Hilvoorde, A. Elling and R. Stokvis, "How to influence national pride? the olympic medal index as a unifying narrative," Int Rev Sociol Sport, vol. 45, no. 1, pp. 87-102, 2010.

[2] L. Allison and T. Monnington, "Sport, prestige and internationa relations," Glob Polit Sport Role Glob Institutions Sport, pp. 5-23, 2005.

[3] H. Groenen, "The International Journal of the History of Sport The Early Development of Women' $\mathrm{s}$ Judo in Belgium from the Liberation to the late 1950s : Emancipation, Sport and Self-defence," pp. 37-41, 2012.

[4] N. Cummings, "Self-Defense Training for College Women," J Am Coll Heal, vol. 40, no. 4, pp. 183-8, 1992.

[5] C.C. Rogers and C.C. Rogers, "Judo: A Sport Fit for Everybody?" pp. 3847, 2017.

[6] D. Sugiyono, Metode penelitian bisnis. Bandung: Pusat Bahasa Depdiknas, 2008.

[7] Berliana, Partisipasi Wanita Dalam Olahraga Prestasi. Bandung: Sekolah Pasca Sarjana UPI, 2009, p. 356.

[8] D. Haycock and A. Smith, "A family affair? Exploring the influence of childhood sport socialisation on young adults' leisure-sport careers in north-west England.” Leis Stud., vol. 33, no. 3, pp. 285-304, 2014.

[9] J. Sadowski, D. Gierczuk and J. Miller, "Success factors in elite WTF taekwondo competitors," vol. 8, no. 3, pp. 141-6, 2012

[10] C. Geertz, Local Knowledge: further essays in interpretive anthropology. London: Fontana, 1993

[11] M. Nicholson, K. Brown and R. Hoye, "Sport in Society: Cultures Commerce , Media , Politics Sport , community involvement and social support," pp. 37-41, 2013

[12] T. Idle, E. Wood, and S. Desmarais, "Gender role socialization in toy play situations: Mothers and fathers with their sons and daughters," Sex Roles, vol. 28, no. 11-12, pp. 679-691, 1993.

[13] K. Green, M. Thurston, O. Vaage and K.M. Moen, "Girls, young women and sport in Norway: a case of sporting convergence amid favourable socio-economic circumstances," Int J Sport Policy, vol. 7, no. 4, pp. 531-50, 2015

[14] F. Skillen, "Woman and the sport fetish: Modernity, consumerism and sports participation in Inter-War Britain,” Int J Hist Sport, vol. 29, no. 5, pp. $750-65,2012$

[15] K. Koentjaraningrat, B. Budhisantoso, J. Danandjaya and P. Suparlan, Kamus Istilah Antropologi. Pusat Pembinaan dan Pengembangan Bahasa, 1984 